\title{
A More Productive Australian Economy
}

\section{Dean Parham}

$\mathrm{T}$

There is mounting evidence that the Australian economy may have moved into a new economic phase in the 1990s. It would be the third phase of development since the Second World War. The first phase was the "golden age' of high rates of growth up until 1973-74. Like many other countries, Australia then moved into a period of macroeconomic instability and slower growth. There was a period of recovery in the second half of the $1980 \mathrm{~s}$, but many of the additional gains achieved then were subsequently reversed in the early 1990 s recession. It has been since the 1990 s recession that the Australian economy appears to have entered its third phase. Up to June 1999, there have been eight years of GDP growth - a period already longer than the previous two expansions - at an average rate of four per cent a year (Macfarlane, 1999).

These three phases differ in terms of the reliance placed on factor accumulation and productivity growth as a source of growth. It can be seen from Table 1 that factor accumulation was the main source in the golden age; and a drop-off in factor accumulation was the main proximate reason for the subsequent slowdown. A feature of the 1990s recovery is the greater reliance on productivity growth. The importance of productivity in the $1990 \mathrm{~s}$ is probably greater than the numbers in Table 1 suggest, since it is very likely that improved productivity has created conditions more conducive to growth in investment and employment.

\section{Table 1: Annual Rates of Growth in Output, Inputs and Productivity} in Australia's Market Sector (per cent per year)

\begin{tabular}{lllllll}
\hline & \multicolumn{2}{c}{ Inputs } & \multicolumn{2}{c}{ Productivity } & \multicolumn{2}{c}{ Output } \\
\hline $1964-65$ to $1973-74$ & 3.4 & $(71)$ & 1.4 & $(29)$ & 4.8 & $(100)$ \\
$1973-74$ to $1990-91$ & 1.9 & $(76)$ & 0.6 & $(23)$ & 2.4 & $(100)$ \\
$1990-91$ to $1998-99$ & 2.0 & $(57)$ & 1.5 & $(43)$ & 3.6 & $(100)$ \\
\hline
\end{tabular}

Note: Numbers in brackets are percentage contributions to output growth.

Despite the length of the current expansion, it might be claimed that it is still too early to declare the 1990s to be more than a transient phase of higher growth.

Dean Parham is Assistant Commissioner, General Research Branch, at the Productivity Commission, Canberra. The views expressed in this paper are those of the author and do not necessarily reflect those of the Productivity Commission. 
But it is argued in this paper that the Australian economy started behaving differently in the 1990s and in a way that holds prospects for continued strong growth in the long term. This paper reviews trends in Australia's productivity performance and illustrates some of the links between productivity and growth in output and Australian living standards. It also attempts to draw out a number of policy and other issues relating to the current period of stronger growth.

\section{The Three Phases of Development}

\section{The 'golden age' period to 1973-74}

A 'golden age' blessed many high-income countries with high rates of growth in productivity and output in the post-war period. This was particularly true of a number of Western European countries and Japan. It was associated with the stimulus of foreign aid for post-war reconstruction, strong domestic demand, an opening up of international trade and capital flows and the transfer of technology from the productivity leader, the United States (Maddison, 1994).

Australia's participation in the golden age was due more to a push for further development than to a reconstruction after the ravages of war. With a catch-cry to 'populate or perish', Australia stepped up long-standing programs of immigration and industry development. Against a trend toward more liberal trade among other high-income countries, Australia maintained and raised trade barriers in the $1950 \mathrm{~s}$ and, to a lesser extent, in the 1960s (Pincus, 1995). The extensive development of minerals and favourable movements in the terms of trade also helped to underpin strong economic performance, especially in the 1960 s and early $1970 \mathrm{~s}$.

The importance of factor accumulation was consistent with the interest in nation building and exploitation of minerals. Factor accumulation was the primary focus, and productivity performance, though relatively high by historical standards, was of more incidental concern. Australia's reliance on factor accumulation was high by international standards, and its reliance on productivity growth was correspondingly low (Elek, Camilleri and Lester, 1989).

Australia's productivity growth did not keep pace with the performance of other high-income countries. Even though Australia's rate of productivity growth was high by historical standards, it did not match the rates of European countries and Japan. To some extent, this could be expected. International catch-up and convergence theory suggests that faster productivity growth can be expected in countries that start with a wider productivity gap against the productivity leader (Abramovitz, 1994). However, even allowing for its relatively strong starting point, Australia's productivity performance was relatively poor. In 1950, Australia had the third highest level of GDP per hour worked at 69 per cent of the US level, while the arithmetic average of (Western) European countries was at 46 per cent, and Japan was at 16 per cent (Maddison, 1995). By 1973, the Europeans had essentially caught up to Australia (70 per cent and 72 per cent of the US level, respectively) and Japan had caught up as far as 48 per cent of the US level. Australia's rate of productivity growth over the golden age had not been sufficient 
to make much progress in catching up further to the productivity leader (a feat which other countries later showed to be possible when they overtook Australia's position).

There was growing awareness in Australia through the 1960s and 1970s that production was not organised in a way that would make the most of available opportunities. Max Corden, for example, was a major influence on academic argument about the costs of import protection for local industry. In 1965, the Vernon Committee outlined the costs of the complex assistance structure that had evolved under 'made-to-measure' tariff setting. The Tariff Board also brought the costs of protection to policy attention. But, while general prosperity continued to grow at satisfactory rates, there was perhaps insufficient political imperative to tackle structural problems that were holding back Australia's growth in productivity and the realisation of its potential in terms of growth in living standards.

The slowdown period, 1973-74 to 1990-91

As in other countries, Australia's golden age came to an end around 1973-74. From that time, there was a deterioration in the terms of trade and a fall in volumes of some traditional exports. Immigration slowed, unemployment and inflation grew, and the rate of investment in mining collapsed. Growth in inputs slowed markedly. There was no productivity response. Indeed, productivity growth slowed. And, as a result, growth in GDP and average income slowed.

Australia's structural problems came to more prominent attention around this time. There was a series of government-commissioned reports - the report of a Working Group (convened by Stuart Harris) of 1974 on rural policy, the Jackson Committee report of 1975 on policies for the manufacturing sector, a government White Paper on manufacturing in 1977 and a Study group (convened by Sir John Crawford) in 1979 on structural adjustment. (See Snape, Gropp and Luttrell, 1998, for comments and extracts from these and other reports.) They had different perspectives, but all included reference to structural problems and adjustment issues facing the Australian economy. From a productivity perspective, these structural weaknesses included: the proliferation of small-scale production facilities covering an excessive product range (at the expense of gains from scale and specialisation); diversion of resources from industries with the best long-term prospects for growth; the focus of manufacturing on the domestic market, leaving a dependence on agricultural and mineral products for export earnings; poor work practices, labour relations and management; and outdated or inappropriate technologies, combined with low innovation and skill development.

Although it did not receive the same attention at the time, there were also inefficiencies in the provision of Australia's economic infrastructure. Government provision of electricity, gas, water, transport and communications had assisted national development and redistribution objectives. But it had also contributed to poor investment decisions and poor operational efficiency. 
As mentioned before, there was a transient period of strong growth in the latter part of the 1980s, due to strong growth in capital (especially in property) and labour inputs (expansion of employment encouraged in part by lower labour costs under the Accords). Productivity growth at this time was at an historical low. But the recovery was accompanied by unsustainable asset prices and credit levels. Recession followed.

The 1980s saw the beginnings of substantial policy reform to tackle structural weaknesses and to rekindle stronger growth. The imperative for policy reform grew as inflation and unemployment problems persisted into the 1980 s and were joined by other concerns, for example, about the outlook for the terms of trade, stronger international competition, Australia's slippage on the international league table of average incomes and its vulnerability on the balance of payments. There were both macroeconomic and microeconomic dimensions to economic reform. Microeconomic reform, which was expected to raise Australia's productivity performance, gathered momentum in terms of coverage and intensity from the late 1980s. Following on from earlier financial deregulation, phased reductions in border protection commenced, reforms to government business enterprises and regulation were initiated and stepped up, and some tentative steps toward labour market reform were introduced.

\section{The 1990s expansion}

The Australian economy appears to have been undergoing a supply-side transformation in the 1990s. Productivity growth has accelerated over the 1990s to outreach the highs of the golden age. Recently, the Australian Bureau of Statistics (ABS) has further revised its productivity estimates. It now puts multifactor productivity growth between 1993-94 and 1998-99 at 1.7 per cent a year (ABS Cat. No. 5204.0). This compares with an historical average from 196465 to 1993-94 of 0.9 per cent a year. The previous record high (over a peak-topeak productivity cycle) was 1.6 per cent a year over the period 1968-69 to 1973 74.

A recent study by the Productivity Commission (PC, 1999) pointed to the following productivity-related changes that began taking place in the 1990s, compared with the past:

- Resources are freer to move to where they can be most productively employed. The pace of structural change has quickened. Resources have left 'traditional' industries, raising the productivity performance of those industries, while there has been strong growth in business-related services (communications, business services, finance and insurance) which can provide these 'growth' services more productively through specialisation, economies of scale and technological advance. Industry composition effects appear have played an unusually large role in Australia's productivity performance in the 1990 s. 
- A greater proportion of investment is being directed toward machinery and equipment rather than buildings. Expenditure on equipment as a proportion of GDP has reached its highest level in over 30 years. A greater proportion of equipment purchases are sourced from overseas, much of it being in computer and telecommunications equipment.

- Firms and industries are being reorganised to concentrate production on a smaller range of products. Production facilities are being rationalised through mergers, takeovers and closures.

- Production is being modernised, with the introduction of more up-to-date technologies. There is also a greater business involvement in innovation and production of innovative products.

- Management skills, incentives and systems are being improved. Work arrangements are being redesigned, assisted by the greater flexibility permitted by enterprise bargaining. The skills of the workforce generally have improved.

A legacy of the pre-reform policy environment was that it encouraged 'development in all directions' (eg 'made-to-measure' tariffs and 'protection all round') and encouraged production and pricing with scant regard to the interests of customers and the wider economy. The emphasis in the 1990s is shifted more to what customers want, where market prospects lie, and the development of products that exploit opportunities to add value. Businesses are taking a longerterm, more strategic view of markets and products, and the production systems they need to fulfil business goals. Flexibility, anticipating and managing change, innovation and productivity are growing in prominence in the business culture.

The Productivity Commission study showed that there have been some strong industry contributors to the improved productivity performance, and that productivity growth in different sectors has picked up at different times. Manufacturing, mining, and electricity, gas and water, made particularly strong contributions in the late 1980s and early 1990s. Agriculture has been a major contributor at various times in the 1990s. Service industries - particularly finance and insurance, wholesale trade, transport and storage, and construction have contributed more in the latter part of the 1990s. Estimates based on recently revised ABS data show a strong pickup in productivity growth for communication services. Evidence of variations in productivity performance across sub-industries and firms within industry sectors is also provided in the Productivity Commission study.

Two implications can be drawn. First, improved productivity performance in the 1990s does not necessarily come predominantly from particular sectors or traditional sources such as manufacturing. A wider range of industries, including service industries, participates and relative contributions change over time. Second, even though differences in productivity performance at more micro levels within industry sectors are unlikely to be eliminated, their presence suggests that there may be scope for further productivity improvement. 
Australia's productivity growth in the 1990s has been in advance of most other high-income countries. Norway and Ireland have also experienced strong productivity growth for reasons that differ from those underlying Australia's productivity surge. There has been much interest in, and debate about, the extent and sources of a productivity growth surge in the US over recent years. While the US experienced a productivity uplift, the improvement in multifactor productivity growth has not been as strong or as prolonged as that evident in Australia.

Australia's 1990s performance reverses à very long history of failing to keep pace with international standards. It is consistent with Australia pursuing some of the catch-up opportunities that were forgone in previous phases. But it is also consistent with some fundamental changes taking place in the Australian economy which place greater emphasis on productivity performance.

\section{Productivity, Economic Growth and Living Standards}

One way of illustrating the growth implications of an acceleration in productivity growth is to examine Australia's growth path. Figure 1 depicts a growth path for the market sector of the economy since the mid-1960s. It plots observations of the output-labour ratio (labour productivity) and the capital-labour ratio. Dividing both output and capital by labour input is a convenient way of capturing the three dimensions of output and inputs of labour and capital in a two-dimensional chart. Because the capital-labour ratio and labour productivity increase over time, the observations line up in chronological order.

Growth based on capital accumulation (or, more correctly, capital deepening - that is, increases in capital per unit of labour) shows up as a growth path drawn out over a wide range of values for the capital-labour ratio. Growth based on productivity growth shows up as a relatively steep gradient in the growth path, since productivity growth means more output for given labour and capital inputs.

A line is fitted through the observations for 1964-65 to 1990-91, corresponding to the first two phases of development discussed in this paper. A line with some curvature is used to allow for the fact that productivity growth slowed in the second phase, so that the historical trend growth path is allowed to flatten out over time in order to provide the best possible fit.

Australia's growth path showed a remarkably stable pattern from the $1960 \mathrm{~s}$ until the early 1990s. The curve fitted from observations for that period shows a very close fit. The 1980 s recession is the only period deviating from the path.

Projecting the fitted line into the 1990 s is a way of illustrating in broad terms what might have happened if the economy had continued on the same historical growth path. It can be seen, however, that the productivity surge in the 1990s led to a steeper growth path, yielding greater increases in output (per hour worked). There could be some argument about the precision in projecting into the $1990 \mathrm{~s}$ on the basis of the historical trend. But, as an illustrative order of magnitude, the value of output (per hour worked) in 1998-99 is about 13 per cent above the projection line. 


\section{Figure 1: Australia's Growth Path, 1964-65 to 1998-99}

$$
\text { Indexes } 1996-97=100
$$

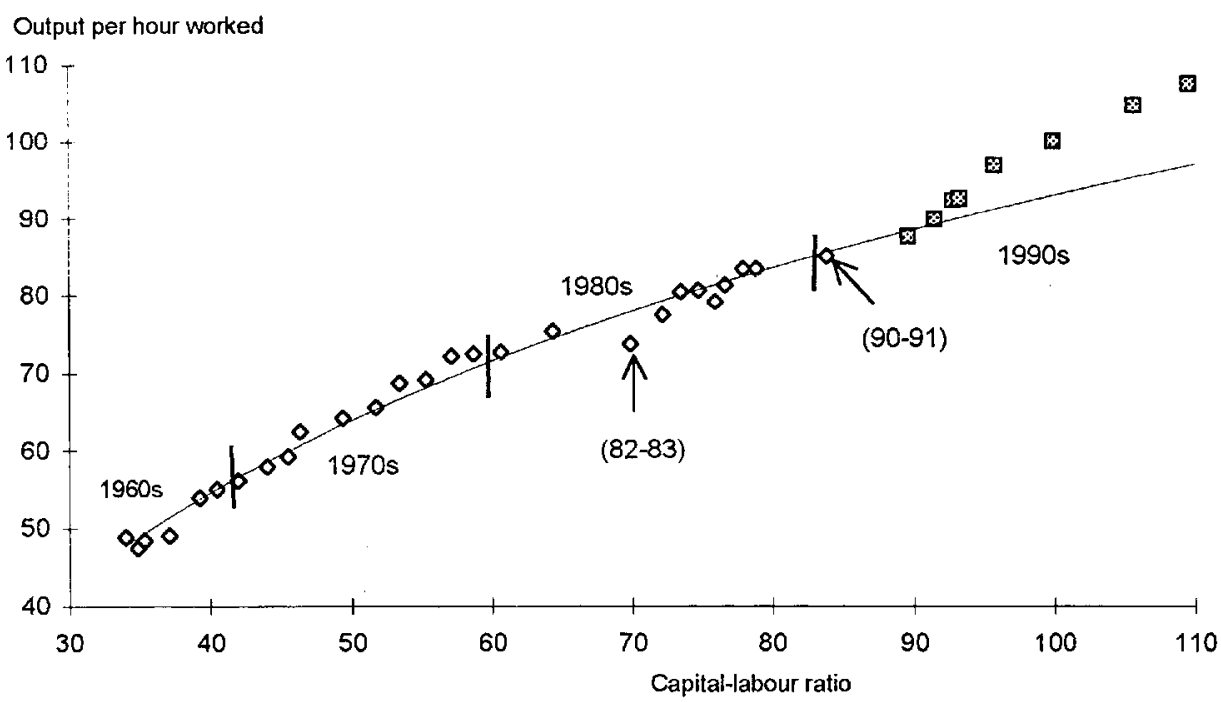

Note: An exponential trend line is fitted for observations up to 1990-91 (end of second development phase) and projected from there. $\mathrm{R}^{2}=0.99$ for the fitted line to 1990-91.

Source: Based on Parham (1999).

One issue is whether the 1990 s productivity acceleration merely stems from recovery from the recession. The normal pattern is for productivity to increase in recovery from a recession as underutilised capacity and hoarded labour become used more intensely. Figure 1 shows a difference between the 1982-83 and 199091 recessions. In 1982-83, labour shedding and the maintenance of underutilised capital led to a more marked shift to the right in the capital-labour ratio. However, a greater reduction in output than in labour meant that labour productivity declined. This would be consistent with there being some remaining labour hoarding. In the recovery from the recession, productivity growth pushed the observations back on to the trend growth path. In the 1990-91 recession, there were again more marked shifts to the right in the capital-labour ratio, but not reductions in labour productivity. The fact that the observations remained on the trend line suggests there was no labour hoarding. In recovery from the recession, the economy took a new growth trajectory. The 1990s productivity surge thus appears to be something more than re-establishing the long-term trend.

Increased productivity growth brings not only faster output growth, but also faster improvement in average living standards. The additional output that productivity growth enables, provides additional income, which can be distributed through:

- better wages and conditions for the existing workforce; 
- increased profits and distributions to shareholders;

- lower prices and better quality products to final consumers (and lower inflation reduces interest rate pressures) and to commercial users;

- $\quad$ increases in government tax revenue (with possibilities to fund tax rate cuts or greater capacity to fund social programs); or

- greater protection for the environment.

Depending on how the gains are distributed, productivity growth can induce further rounds of increased employment and investment. Wage increases would tend to moderate employment growth, whereas price decreases would tend to induce greater output and employment effects. Increased profitability would tend to induce further investment.

Productivity growth is generally regarded as the most important determinant of living standards over the long term. (See IC, 1997 for a formal exploration of the links.) Figures 2 and 3 show that, broadly, there has been a strong correlation between productivity and real domestic income per head (GDP per head adjusted for the terms of trade). The trends are drawn on a log scale, so that the slope of a straight line depicts a rate of growth. (The productivity chart refers to the market sector of the economy, whereas the income chart refers to the economy as a whole.) There are two minor differences between the trends. First, productivity continued to grow at golden age rates through to 1978-79, reflecting a contraction in growth in inputs which maintained productivity growth in the short term. Second, as previously outlined, the stronger income growth in the latter part of the 1980 s was accompanied by low measured productivity growth.

Growth in real average incomes in the 1990 s (3.0 per cent a year) returned to rates of the 1960 s (also 3.0 per cent a year). The rate of growth from the mid1970 s to the mid-1980s was around 1.2 per cent a year.

While average incomes provide an (approximate) indication of average standards of living, there are other dimensions of living standards to consider. The distribution of productivity gains is a major issue. As recognition grows that the economy is performing consistently well, concern is turning to how evenly the gains are being distributed. The specific effects of productivity gains on income distribution have not been studied. But it can be observed that, while earnings and private income inequality increased between 1982 and 1993-94, it was offset at the lower end by increasing progression in income tax scales and, in particular, government cash transfers (Harding, 1997). The ABS has found the distribution of income to have remained almost unchanged between 1994-95 and 1997-98 (ABS Cat. No. 6523.0).

It is also important to note that the surge in productivity in the 1990 s has not come at the expense of employment.

- The employment rate (ratio of employment to the size of the population aged 15-64) has increased over the 1990s to reach the same high achieved at the end of the 1980 s employment expansion.

- The unemployment rate has declined over the $1990 \mathrm{~s}$, since the recession. 
- During the latest productivity cycle (1993-94 to 1998-99) in which productivity growth has been at a record high, market sector growth in labour input (hours worked) has been high by historical standards (1.3 per cent a year compared with 0.9 per cent a year up to 1993-94).

Figure 2: Real Gross Domestic Income Per Head, 1959-60 to 1997-98 (1989-90 dollars, log scale)

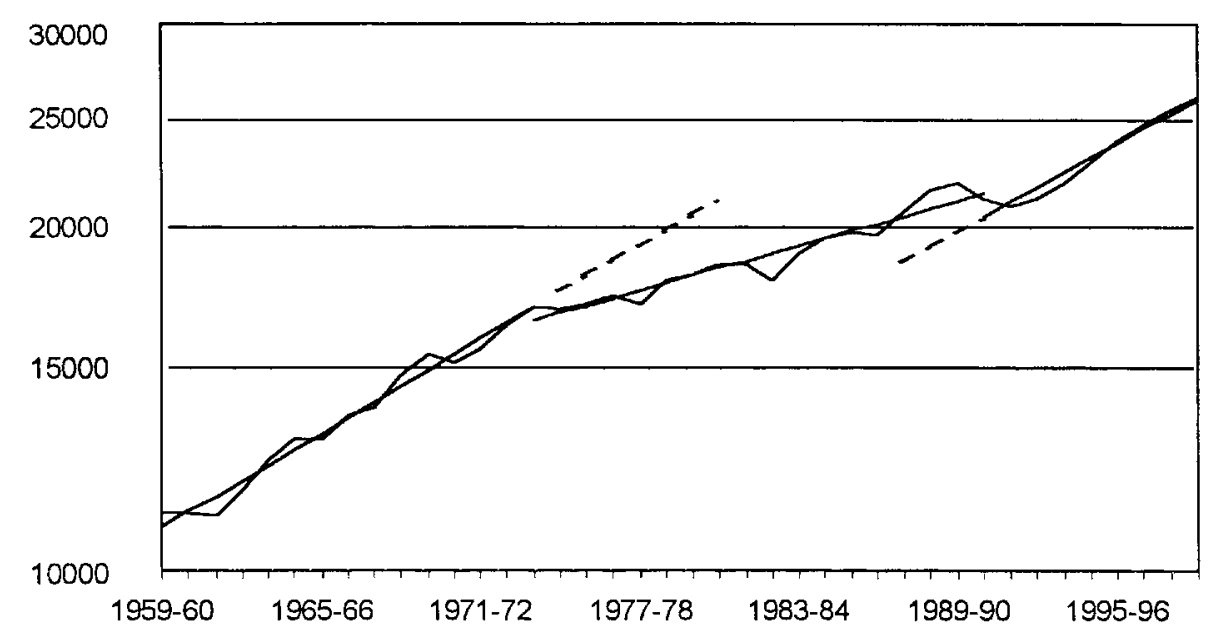

Source: Data from ABS Time Series Statistics on Econdata Data.

Figure 3: Multifactor Productivity (Market Sector) 1964-65 to 1998-99 (Index 1997-98 = 100, log scale)

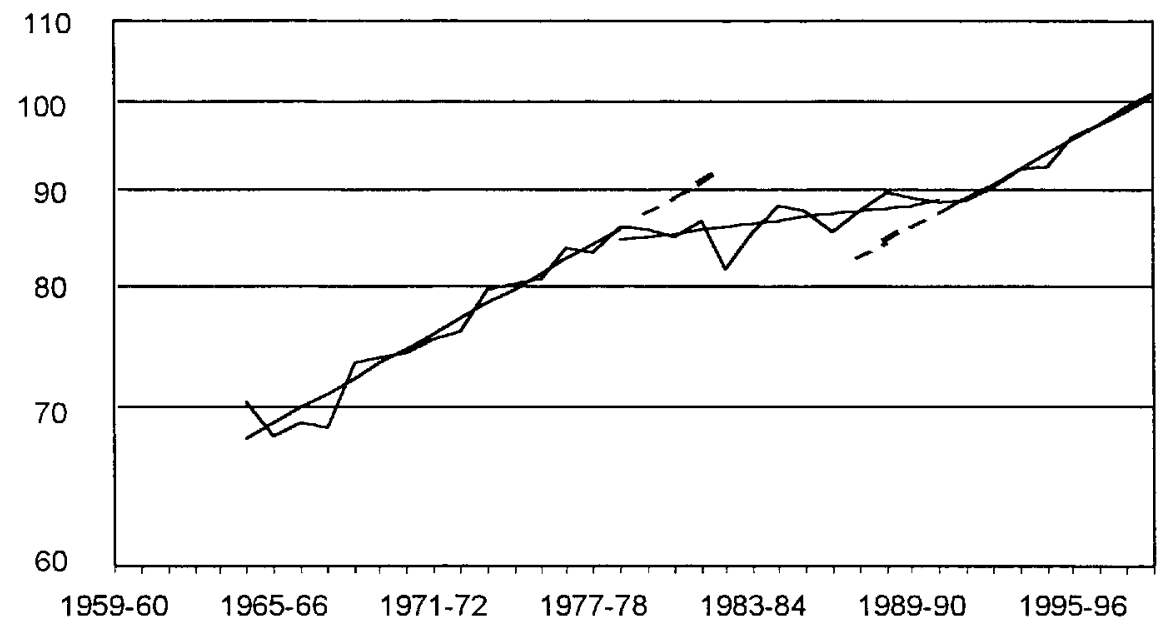

Source: Data from ABS Cat. No. 5204.0. 
In other words, and bearing in mind also the growth in capital input, the historically high rate of productivity growth over recent years does not amount to 'doing more with less'. It is 'doing more with more'.

Productivity growth also enables the community to support higher spending - enjoying more of the fruits of consuming goods and services (be it necessities such as food and schooling or luxuries such as more expensive cars or holidays). All other things equal, relying on capital accumulation to underpin growth requires Australians to save more in order to help finance the growth in investment expenditure without running into balance of payment problems. It also defers the realisation of gains in living standards to some time in the future. However, relying more on productivity to underpin growth, means Australians are in a better position to spend now and not run (as readily) into balance of payments difficulties.

Some welfare considerations - though relevant - have been linked inappropriately to productivity. In particular, concerns have been raised about the welfare implications of increased working hours and unpaid overtime. However, it would be wrong to attribute Australia's productivity improvement to longer working hours as suggested by some. Additional working hours, whether paid or unpaid, contribute to output through input growth and not productivity growth.

\section{Policy Issues and Perspectives}

The improved productivity performance of the 1990s raises at least three general questions.

- What has been the role and importance of microeconomic reform in raising Australia's productivity performance and, therefore, how important is it to a continuation of strong productivity growth?

- Can the improved productivity performance be sustained?

- What are the implications for the distribution of burdens and gains among Australians?

\section{Role of microeconomic reform}

The introduction of microeconomic reforms was intended to bring a number of welfare gains on both the demand and the supply sides of the economy. Reforms were expected to boost Australia's productivity performance by:

- enabling greater flexibility in the economy so that resources could be attracted to more productive uses;

- improving technical efficiency; and

- encouraging a more 'dynamic' business culture that would enable Australian firms to be more self reliant and better able to meet the challenges of fiercer international competition, technological advance and globalisation. 
The structural changes that have taken place in the economy over the past decade or so, as outlined above, are in keeping with the expected outcomes of microeconomic reforms. Reductions in trade and regulatory barriers have enabled a freer movement of resources to where growth prospects lie. Reform in capital and labour markets has enabled a better allocation of resources. Enhanced competitive pressures and, in the case of government business enterprises, a clear commercial focus have provided incentives for firms to improve efficiency, not only by cutting unnecessary costs, but also by upgrading technologies and becoming more active in innovation. Openness to foreign trade and investment is bringing access to technologies, ideas and expertise and has encouraged greater specialisation.

Reforms have also brought changes in the attitudes of domestic producers. A previous reliance on tailored government assistance to underwrite and protect market positions has given way in large part to greater self-reliance among businesses and industries and to a focus on business improvement as a means of securing growth and profitability.

Reform case studies conducted by the Productivity Commission (PC, 1999) provided illustration of the potential benefits of a change in expectations. The whitegoods, automotive, and textiles, clothing and footwear (TCF) industries were in quite similar positions in the 1970 s - mature, highly-assisted industries, which were afforded the protection of quotas. All were subsequently subjected to reductions in protection. However, protection was reduced in whitegoods earlier, quicker and to a greater extent than in the other industries.

Having realised by the mid-1980s that the government policy stance toward support of the whitegoods industry had changed, the local industry went through a period of relatively rapid adjustment to become internationally competitive. Automotive and TCF, although provided with extensive forms of adjustment assistance, were slower to adjust and have been much slower to raise productivity.

There have been marked improvements in productivity performance in areas of economic infrastructure traditionally dominated by government business enterprises. Bringing the discipline and opportunities of a clear commercial focus and clear accountability for performance have been key changes. Productivity gains in a number of industries and particular enterprises have been quite spectacular.

But it would be overstating the case to attribute all the productivity improvement to microeconomic reform. The resumption and maintenance of a more stable macroeconomic environment, through monetary and fiscal measures, has undoubtedly made a contribution. For example, sound macroeconomic management was a factor sustaining output over the period of uncertainty created by the Asian economic crisis.

It is also possible that underlying technological advances (for example, the use of fibre-optics in communications) may have contributed to some of the productivity improvement. However, Australia's long history of lagging in the adoption of technologies prior to reform would caution against overstating the 
speed of adoption of advances in the absence of the competitive and commercial incentives that were strengthened by the introduction of microeconomic reforms. In addition, many technological advances are embodied in new equipment purchases and are counted by the statistician as part of capital inputs rather than productivity.

\section{The productivity growth outlook}

The outlook for continued strong productivity growth seems favourable. Greater exposure to competition and the greater commercial focus of government business enterprises provide ongoing incentives to seek out better products and better ways of doing things. A more 'dynamic' business culture reinforces the focus on productivity. There are also greater flexibilities to improve business operations. For example, less unnecessary regulation and new enterprise bargaining structures enhance the ability of firms to reorganise production and redesign work arrangements. As noted above, the evidence that improved productivity performance is still patchy at a micro level suggests that there is still scope for further improvement.

That is not to say that there will be immunity from demand-side shocks, such as downturns in external markets. But, even here, it can be noted that the economy has become much more resilient. It posted record productivity growth in the midst of the Asian economic crisis. In part, this was due not only to good macroeconomic management, but also to the fact that producers are more flexible, more aware of markets and anticipate and manage risks better.

If the rest of the world were to stand still, Australia's relatively high rate of productivity growth could be expected to slow at some point as available, catch-up opportunities become fully realised. But the rest of the world does not stand still. The increase in productivity growth in the US in recent years may signal that a new frontier of productivity improvement is opening up. (While benefits from an information technology 'revolution' are much discussed, there is insufficient consensus for a firm conclusion on the underlying reasons.) But, if this is the case, Australia is positioning itself well through the process of renewal of production, to incorporate any new developments that can be used to advantage. Rather than falling further behind as it would have in the past, Australia is now better placed to ride on the crest of a longer wave of productivity improvement. Our ability to succeed in this regard, however, will depend also on the flexibility provided by ongoing reform, the development of necessary skills and the presence of sound institutional supports.

\section{Distributional issues}

The distribution of the gains from economic progress is an important issue. Distributional matters are a key component of living standards. And Australians have a strong egalitarian ethic. Distributional issues may well come further to the fore in policy debates if the period of improvement in general prosperity 
continues. There has been discussion already of a divide between urban and rural communities; and the extent of the benefits received by top executives.

While distributional issues are real and need to be addressed, the improvement in prosperity that productivity growth generates provides more of an opportunity than a problem. As Lester (1998:45) observed in the productivity context, "... a rising tide will not lift all boats. However, a more rapidly rising tide will certainly leave fewer boats stranded.'

Some of the issues to be sorted out are as follows:

- Is some inequality in the distribution of the gains inevitable and tolerable, for example, to provide reward for entrepreneurial endeavour and to compensate those who take the risks?

- To what extent is it a problem if all are made better off in absolute terms, but some receive greater gains than others?

- Who is missing out and what is the best way to help them? What is the best way to include those not participating strongly in market activities in the distribution of the gains?

- Productivity growth provides the wherewithal in the long term to pursue community objectives, including social and environmental goals, more thoroughly and vigorously. Are there tradeoffs between pursuing productivity improvements and broader community objectives? How can any potential conflicts be best mitigated?

\section{Concluding Remarks}

The Australian economy appears to have moved into a new phase of higher growth in the 1990s. A heavier reliance on productivity as a source of growth stands out as a break from the past. Australia has turned around a long history of poor productivity performance by international standards. The fact that Australia's rate of productivity growth was higher than nearly all other highincome countries in the 1990s suggests that a domestic explanation for the improvement is required. Some success in explicit attempts to raise Australia's productivity performance by introducing microeconomic reforms is an important part of the explanation.

Stronger productivity growth not only underpins faster output growth, but it also brings forward improvements in average living standards. The improvement in prosperity provides greater opportunity over the long term to pursue community goals.

The prospects for sustained improvement in Australia's productivity performance seem favourable. They will be reinforced by ongoing commitment to policy reform. From a welfare point of view, attention will also need to be given to how the gains are distributed. 


\section{References}

Abramovitz, M. (1994), 'Catch-up and Convergence in the Postwar Growth Boom and After', pp. 86-125 in W. Baumol, R. Nelson and E. Wolff (eds), Convergence of Productivity, Oxford University Press, New York.

Elek, A., A. Camilleri, and M. Lester (1989), 'Innovation and Technological Change in Australia: Problems and Prospects', pp. 190-209 in B. Chapman (ed.), Australian Economic Growth: Essays in Honour of Fred H. Gruen, Centre for Economic Policy Research, The Australian National University, Canberra and Macmillan, South Melbourne.

Harding, A. (1997), 'The Suffering Middle: Trends in Income Inequality in Australia, 1982 to 1993-94', Australian Economic Review 30(4):341-58.

IC (Industry Commission) (1997), Assessing Australia's Productivity Performance, Research Paper, AGPS, Canberra.

Lester, R. (1998), The Productive Edge: How US Industries Are Pointing the Way to a New Era of Economic Growth, W. W. Horton and Co, New York.

Macfarlane, I. (1999), 'Monetary Policy in Economic Expansions', Chris Higgins Memorial Lecture, Australian Academy of Science, Canberra, 27 October.

Maddison, A. (1994), 'Explaining the Economic Performance of Nations, 1820-1989', pp. 20-61 in W. Baumol, R. Nelson and E. Wolff (eds), Convergence of Productivity, Oxford University Press, New York.

Maddison, A. (1995), Monitoring the World Economy 1820-1992, OECD, Paris.

Parham, D. (1999), The New Economy? A New Look at Australia's Productivity Performance, Productivity Commission Staff Research Paper, AusInfo, Canberra.

PC (Productivity Commission) (1999), Microeconomic Reform and Australian Productivity: Exploring the Links, Commission Research Paper, AusInfo, Canberra.

Pincus, J. (1995), 'Evolution and Political Economy of Australian Trade Policies', pp. 5373 in R. Pomfret (ed.), Australia's Trade Policies, Oxford University Press, Melbourne.

Snape, R., L. Gropp and T. Luttrell (1998), Australian Trade Policy 1965-1997: A Documentary History, Allen and Unwin, Sydney.

This article draws on work undertaken by colleagues at the Productivity Commission. I am grateful to Paul Roberts for assistance in preparing the charts. I also acknowledge helpful comments from Richard Snape, the Editor and an anonymous referee. The usual caveat applies. 